\title{
The art of animal colouring
}

\author{
Dazzled and Deceived: Mimicry and \\ Camouflage \\ by Peter Forbes \\ Yale University Press: 2009. 304 pp. \\ $\$ 27.50, £ 18.99$
}

In Dazzled and Deceived, science writer Peter Forbes examines the role of animal coloration in aiding our understanding of evolution. In particular he looks at protective colouring, which links many aspects of evolution, from genes to selection. It is nature's artwork, he explains, and the painters who decide what is on the canvas are the predators.

Forbes highlights two types of coloration that exploit imitation to foil potential predators. Cryptic animals blend into their backgrounds and may also mimic inanimate forms. For example, the closed wings of the Indian leaf butterfly (Kallima inachus) (pictured) look like foliage to dissuade birds from eating it. Others use vivid patterning as a warning - the bright bands of Heliconius butterflies convey the message to predators that the insects are toxic.

Butterflies have been especially significant in helping us to unravel the mechanisms that promote similarity in coloration. Patterns that bird predators find easy to avoid will be favoured. These insects use appropriate strategies to fool even experienced predators - Kallima butterflies do not copy one particular leaf exactly, but may take on the characteristics of several types of leaf so that they blend in with their surroundings. By contrast, different Heliconius butterflies must share and copy particular warning patterns accurately to be effective.

To explain how the theory of protective coloration has developed, Forbes takes the reader through studies of variation in the colour forms, the genes that code for colour variation and tests of how predators select for and prey on different patterns. The genes for colour-pattern

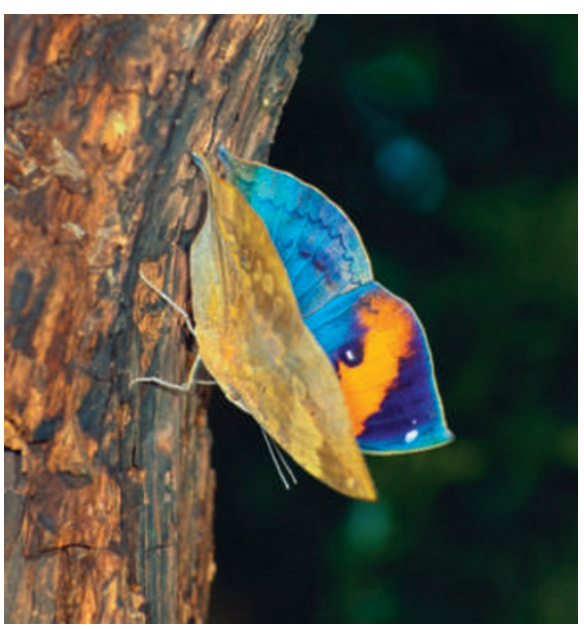

The leaf-like pattern on the underwing of Kallima inachus can render the resting butterfly invisible.

variation among Heliconius butterflies, for instance, are close to being fully sequenced. In the future, researchers may be able to transplant these colour genes to different species to study how the colour patterns change, and test how these new forms will be selected by predators. It should then be possible to witness the evolution of colour changes and mimicry in real time.

The book highlights the interlinked nature of science. To understand the development of the theory of protective coloration, we must first understand how the theory of evolution progressed, as well as genetics, developmental biology and experimental science in general. In turn, Forbes illustrates how advances in protective coloration have affected evolutionary theory. He reminds us that the surrounding world affects how science is done, and that science affects the world.

He also conveys that science is a human endeavour. Although we know a lot about the thoughts of early naturalists, such as Charles
Darwin, from their diaries and writings, we know little about what inspires modern scientists. Forbes remedies this by interviewing researchers in the field of animal coloration. Yet most seem to be more focused on getting results than explaining the world behind the scientific stage.

Forbes ventures beyond the scientific literature by considering the influence of artists on theories of coloration at the beginning of the twentieth century. The American painter and naturalist Abbott $\mathrm{H}$. Thayer, for example, defined two terms of cryptic coloration that are still used today: countershading - a colour scheme in which those parts of an animal that are most illuminated are dark, and vice versa - and disruptive coloration, in which the outline of an individual is broken by random patches of colour. Thayer went so far as to suggest that all animals are cryptic in their surroundings - such as pink flamingos against the evening sky (see Nature 458, 705; 2009). These ideas were seen as too extreme and were heavily criticized. Nevertheless Thayer's 1909 book on natural colouration influenced the patterns of military camouflage in the First World War. Forbes sees another parallel between disruptive coloration and art in the use of naturalistic colour schemes and abstracted forms by the cubist movement, for instance, in the work of Pablo Picasso.

As zoologist Hugh Cott remarked, "The one [art] makes something unreal recognizable; the other [nature] makes something real unrecognizable." In this excellent and wide-ranging book, Forbes makes the hidden histories of science recognizable.

Leena Lindström is at the Centre of Excellence for Evolutionary Research, Department of Biological and Environmental Sciences, Fl-40014 University of Jyväskylä, Finland.

e-mail: leena.m.lindstrom@jyu.fi

\section{Distorting the climate message}

\section{Climate Cover-Up: The Crusade to Deny Global Warming \\ by James Hoggan with Richard Littlemore Greystone Books: 2009. 224 pp. US\$15, Can $\$ 20$}

Now that the Copenhagen climate negotiations have passed, it may seem as if those who deny the existence of climate change have faded into the background. Yet, in Climate Cover-Up, James Hoggan and Richard Littlemore argue that we should never stop paying attention to the pervasive influence of climate-change scepticism.

Since 2006, the authors have been running the climate blog DeSmogBlog.com. Through this, they aim to combat what they see as a massive, ongoing public-relations campaign to distort people's perception of climate change by presenting scientific conclusions as biased. Hoggan is president and founder of a public-relations company in Vancouver, Canada, and also sits on the board of the David Suzuki Foundation, a science-based Canadian environmental organization. From this vantage point he became disgusted by how the tools of his trade were being misapplied. He argues that the public-relations business includes a duty to society to practise with "truth, accuracy, fairness, and responsibility to the public". But when public-relations people confuse their role and become advocates for their clients, their tactics may veer into unethical terrain.

Hoggan and Littlemore, who is a journalist and speech-writer, document the unfolding of a multi-pronged public-relations assault on the 